\title{
PRODUCTION OF BIOGAS FROM CO-DIGESTION OF EMPTY FRUIT BUNCHES (EFB) WITH PALM OIL MILL EFFLUENT (POME): EFFECT OF MIXING RATIO
}

\author{
C. S. Octiva ${ }^{1}$, Irvan ${ }^{1,2}$, M. Sarah ${ }^{1,2}$, B. Trisakti ${ }^{1,2}$ and H. Daimon ${ }^{3}$ \\ ${ }^{1}$ Department of Chemical Engineering, Universitas Sumatera Utara, Medan, 20155, Indonesia \\ ${ }^{2}$ Sustainable Energy and Biomaterial Center of Excellence, Universitas Sumatera Utara, \\ Medan, 20155, Indonesia \\ ${ }^{3}$ Department of Environmental and Life Sciences, Toyohashi University of Technology, \\ Toyohashi, 441-8580, Japan \\ *E-mail: irvan@usu.ac.id
}

\begin{abstract}
A huge production of palm oil mill effluent (POME) and empty fruit bunches (EFB) from palm oil mills become a serious problem, nowadays. Many methods are already studied to utilize these side products in various applications; one of them is the conversion of POME and EFB to biogas. In this study, the effect of mixing ratio of POME and EFB substrate on biogas production was investigated. The experiment was performed in a batch reactor with a working volume of 6 liters of the reactor under thermophilic temperature $\left(55^{\circ} \mathrm{C}\right)$. Experiments were conducted by varying the ratio of POME and EFB (20:1, 25:1, 30:1, 35:1, and 40:1). Co-digestion POME and EFB with mixing ratio $35: 1$ was considered as the suitable ratio which reaching highest gas production of $80.30 \mathrm{~L} / \mathrm{mg}$.VS , highest COD reduction of $63.1 \%$, and highest methane content of $80.10 \%$.
\end{abstract}

Keywords: Palm oil mill effluent, empty fruit bunch, biogas, co-digestion, thermophilic

(C) RASĀYAN. All rights reserved

\section{INTRODUCTION}

By 2015, from 11.3 million hectares of palm oil mill plantation in Indonesia, palm oil mill effluent (POME) reaches \pm 82.5 million tons ${ }^{1,2}$. Besides POME, the mill also generates empty fruit bunch (EFB) $(23 \%)$, mesocarp (12\%) and shell $(5 \%)$ for each ton of fresh fruit bunches (FFB) processed at the mill ${ }^{3}$. EFB is one of the most common types of solid waste produced from palm oil production after POME which is one of the byproducts of palm oil mill from condensate sterilization process (36\%), water clarification process $(60 \%)$, and hydro cyclone water (4\%). EFB is the main by-product from the palm oil mill with every $1000 \mathrm{~kg}$ of fresh fruit bunches will produce $220 \mathrm{~kg} \mathrm{EFB}^{4,5}$. Commonly, most EFB is used as mulch on palm tree lands by spreading EFB around the trees. Although the presence of mulch is useful to avoid weeds, keep the moisture and stop soil erosion but its application is expensive. Moreover, it does not only create environmental pollution problems but it also offers limited value to the industry. Several approaches have been developed to apply EFB fibers to produce valuable materials such as paper pulp, composite boards, thermoset polymer, and microporous activated carbon ${ }^{6}$.

Irvan et al in 2012 performed biogas production from POME using anaerobic microbes in a 2 (two) liters digester at a temperature of $55^{\circ} \mathrm{C}$ (thermophilic), closed systems, intermittent, hydraulic retention time (HRT) variation and recycle sludge ${ }^{7}$. In this experiment, the removal efficiency of COD could be achieved to 85\% at HRT 6 days. In 2016, they have scaled up the process from laboratory scale to pilot scale, they reported the performance of the two different scales under the same conditions and same $\mathrm{POME}^{8}$.

POME could be easily converted to biogas in relatively short time (HRT 6 days) then used in many applications, while solid waste (FFB) are not utilized for biogas production, due to its composition are difficult to degrade by microorganisms. Many studies have been performed in order to treat POME and 
EFB to biogas in a digester, such as research conducted by Nurliyana et $\mathrm{al}^{4}$. They investigated methane production with POME and EFB substrates which performed with different EFB and POME loadings at room temperature of $27-30 \circ \mathrm{C}$ (mesophilic) and facultative condition. Since POME and EFB are composed of many saturated fatty acids and cellulose which are very hard to degrade at room temperature, therefore the objective of this research was to study the performance of a batch reactor with a working volume of six liters, by varying mixing ratio of POME and EFB in volume/mass under thermophilic condition $\left(55^{\circ} \mathrm{C}\right)$.

\section{Material and Methods}

\section{EXPERIMENTAL}

Palm oil mill effluent and empty fruit bunches as raw materials were obtained from local palm oil factory (Rambutan Mill, North Sumatra, Indonesia). POME was obtained from the fat pit of factory's wastewater treatment installation and stored in some clean $20 \mathrm{~L}$ container. It was transported to the laboratory, mixed well, put in 1-liter plastic bottles, and stored at $4{ }^{\circ} \mathrm{C}$ until further use. EFB was taken from the shredder. EFB was then dried under the sun and cut for reducing the particle size $\pm 5 \mathrm{~cm}$ and then oven dried at 105 ${ }^{\circ} \mathrm{C}$ for overnight. POME was analyzed by following standard method for determination of its main composition ${ }^{9}$. Table-1 summarizes the main properties of POME.

Table-1: Properties of POME from Rambutan Mill

\begin{tabular}{l|c|c|c}
\hline \multicolumn{1}{c|}{ Parameter } & Units & Values & Method \\
\hline $\mathrm{pH}$ & - & $3.60-4.80$ & APHA 4500-H \\
\hline Chemical Oxygen Demand (COD) & $\mathrm{mg} / \mathrm{L}$ & 48,500 & APHA 5220B \\
\hline Total Solid (TS) & $\mathrm{mg} / \mathrm{L}$ & $13,400-37,000$ & APHA 2540B \\
\hline Volatile Solid (VS) & $\mathrm{mg} / \mathrm{L}$ & $10,500-31,200$ & APHA 2540E \\
\hline Total Suspended Solid (TSS) & $\mathrm{mg} / \mathrm{L}$ & $2,100-27,100$ & APHA 2540D \\
\hline Volatile Suspended Solid (VSS) & $\mathrm{mg} / \mathrm{L}$ & $1,900-25,900$ & APHA 2540E \\
\hline
\end{tabular}

\section{Experimental Method}

The fermentation process occurred in a batch reactor with 8-liter capacity and 6-liter working volume at thermophilic temperature. The reactor was provided with a water bath to control the temperature, thermometer, sampling injector and graduated cylinder to measure the biogas production. Fig.-1 shows the experimental set up of batch reactor used in this experiment. Fresh POME without further treatment was used as feed, while thermophilic bacteria as a starter was obtained from a biogas pilot plant installation located at a Centre of Community Service of Universitas Sumatera Utara ${ }^{1,8}$. The fresh feed put into the reactor consists of $15 \%$ starter and the rest is a mixture of POME and EFB. pH liquid inside the reactor was maintained at $7 \pm 0.2$ by adding $\mathrm{NaHCO}_{3}$. The parameters such as $\mathrm{pH}, \mathrm{M}$-alkalinity, total solids, and volatile solid of liquid were analyzed daily, while COD was measured once in every three days, according to Standard Methods for the Examination of Water and Wastewater (APHA) ${ }^{9}$. Biogas generation was recorded by using graduated cylinder while its content was measured by a biogas analyzer (SAZQ).

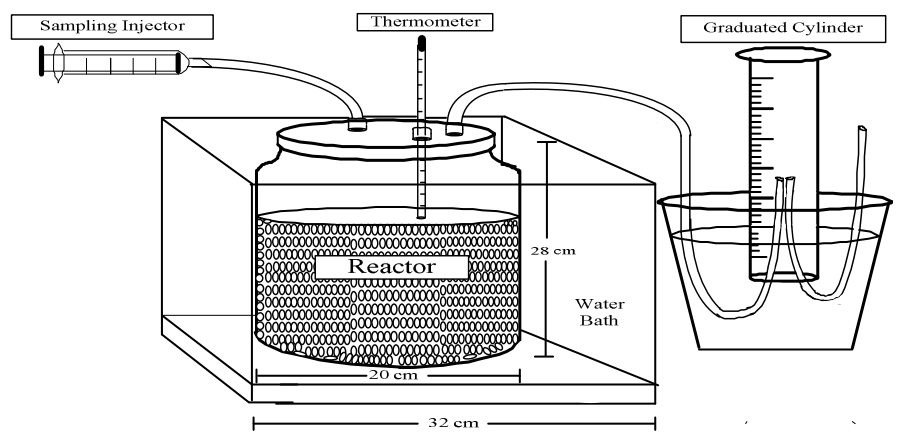

Fig.-1: Experimental Set Up for Biogas Production from POME and EFB 


\section{Effect of Mixing Ratio on Alkalinity}

\section{RESULTS AND DISCUSSION}

Alkalinity is a parameter in anaerobic digestion operation which is a measure of the capacity of alkalinity to neutralize acid ${ }^{10-12}$. The alkalinity of the methanogenesis process reflects the buffer's capacity to the acid, and can also effectively neutralize the $\mathrm{pH}$ rapidly. The effect of mixing ratio on alkalinity is shown in Fig.-2.

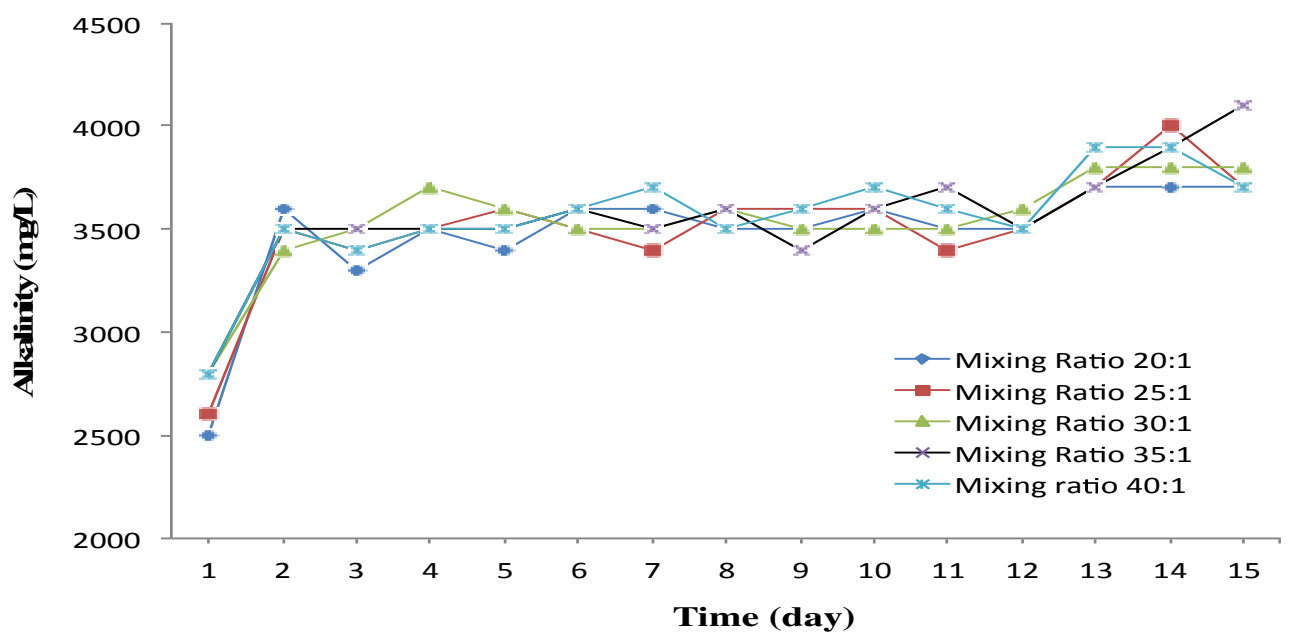

Fig.-2: Effect of Mixing Ratio of POME and EFB Substrate on Alkalinity

As shown in Fig.-2, the mixing ratio of POME and EFB substrate on alkalinity have a similar trend. On the first day for each ratio of POME and EFB, the alkalinity values are still low. The lowest values are found in the mixing ratio of 20:1 and 25:1, reaching 2,500 mg/L. Then from day 2 to day 15 , the values of alkalinity slightly fluctuate. Fluctuations in alkalinity values occur as the $\mathrm{pH}$ change in the reactor. However, the alkalinity values obtained in this study fall into a reasonable range of $2,500-5,000 \mathrm{mg} / \mathrm{L}^{10}$, ${ }^{11}$ for the fermentation process.

\section{Effect of Mixing Ratio on Volatile Solid (VS)}

According to Mehta et $\mathrm{a}^{13}$ volatile solid (VS) is a reliable parameter for showing the degradation of organic matter over time, and consequently, is an indicator of the potential for methane production. The effect of mixing ratio on solid volatile (VS) can be seen in Fig.-3.

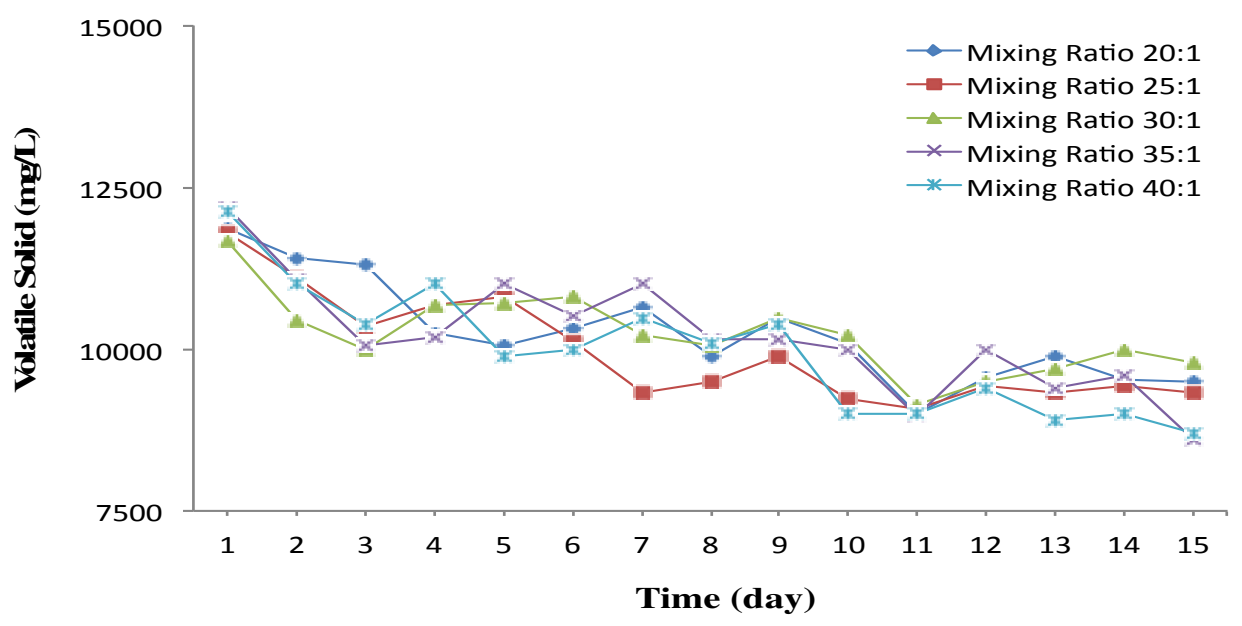

Fig.-3: Effect of Mixing Ratio POME and EFB on Volatile Solid 
Figure-3 shows VS changes in mixing ratio of POME and EFB every day, from the beginning until the 15 days of the experiment. VS value shows slightly fluctuated from day to day for each run of the experiment and the tendency of VS values to decline during the experiment. The value of fluctuating VS was caused by the unstable system, where the growth of microorganisms is still occurring, then allowing the change of VS over time. The lowest VS values for each mixing ratio POME and EFB was plotted in Fig.-4.

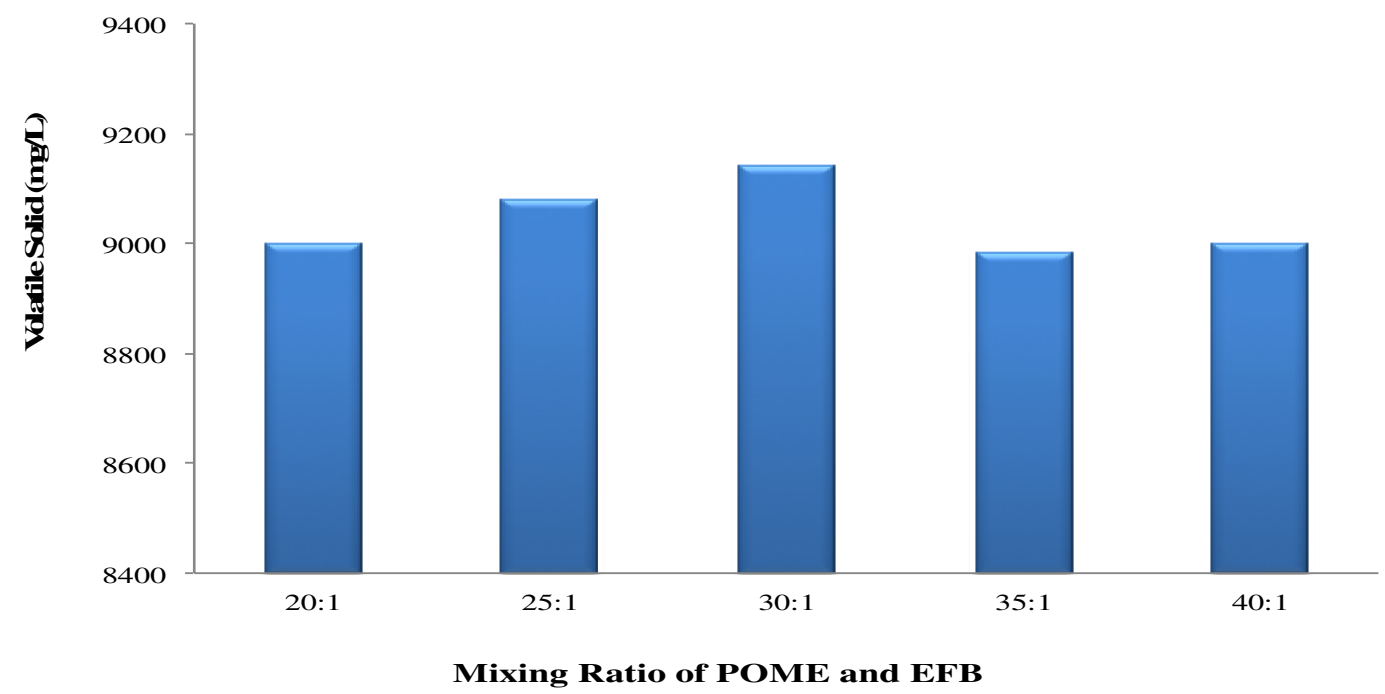

Fig.-4: The Lowest VS Values for Each Mixing Ratio

The lowest value of VS was obtained at mixing ratio of $35: 1$ reached $8,980 \mathrm{mg} / \mathrm{L}$ with $25.91 \%$ of VS reduction. In a study by Babae and Shayegan ${ }^{14}$ with differences in OLR, 1.5; 2 and 2.5 the highest reduction VS was obtained at 1.5 , reached $88 \%$ of VS reduction. In the methanogenesis process of POME : EFB under the thermophilic condition, the optimum ratio was obtained at the mixing ratio of $35: 1$ with a VS reduction value of $25.91 \%$. Raposo et al. ${ }^{15}$ suggested that higher reduced VS indicates that more organic matter is converted by microbes in the reactor.

\section{Effect of Mixing Ratio on Chemical Oxygen Demand Reduction}

Chemical Oxygen Demand (COD) shows the number of organic compounds contained in VFA ${ }^{16}$. The effect mixing ratio of POME and EFB on COD degradation is shown in Fig.-5.

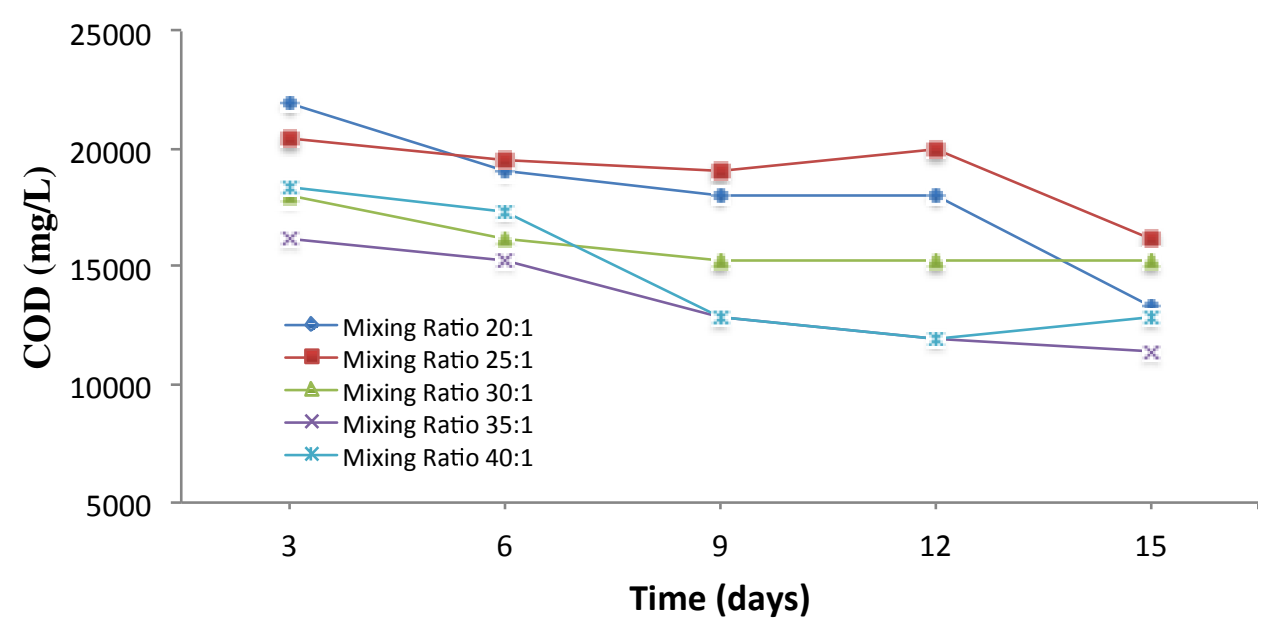

Fig.-5: Effect of Mixing Ratio on COD 
As seen in Fig.-5, changes in COD values tend to decrease and fluctuate. The decrease in COD indicates that microorganisms work well so that the process can take place because it can degrade organic compounds in liquid waste ${ }^{17}$. COD fluctuates in different reactors because all levels of bacterial growth are instability in the adaptation period of microorganisms ${ }^{18}$. The lowest COD reduction value for each mixing ratio is found on day 15. Percentage of COD reduction for each mixing ratio is shown in Fig.-6.

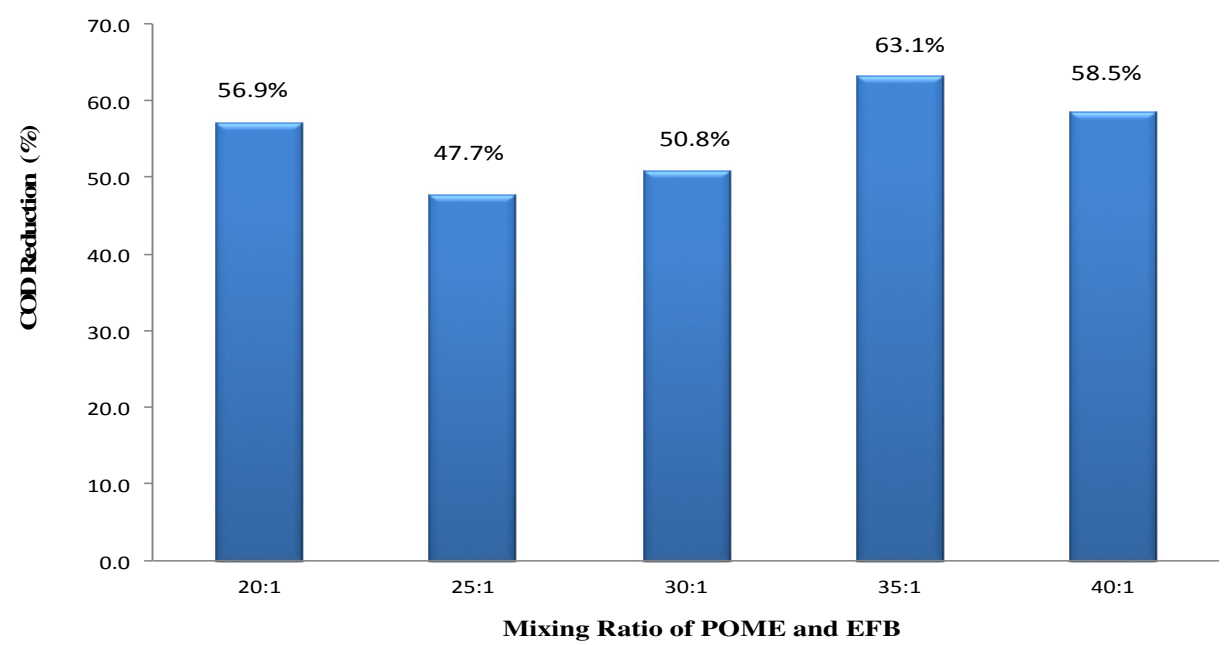

Fig.-6: Reduction of COD for Various Mixing Ratio on Day 15

As shown in Fig.-6, the highest COD reduction, 63.1\% was obtained by mixing ratio of POME and EFB of $35: 1$. Babaee and Shayegan ${ }^{14}$ conducted research using vegetable waste substrate, with a variation of OLR were 1.5, 2 and $2.5 \mathrm{~kg}$. They obtained the best COD reduction was $65 \%$ at OLR $1.5 \mathrm{~kg}$. The increase in OLR beyond the optimum level is followed by the decline in major process parameters such as COD reduction and methane production ${ }^{19}$.

\section{Effect of Mixing Ratio on Biogas Production}

The last stage in anaerobic digestion process is a methanogenesis stage, where biogas is produced. Table2 shows the profile of biogas production for the various mixing ratio of POME and EFB.

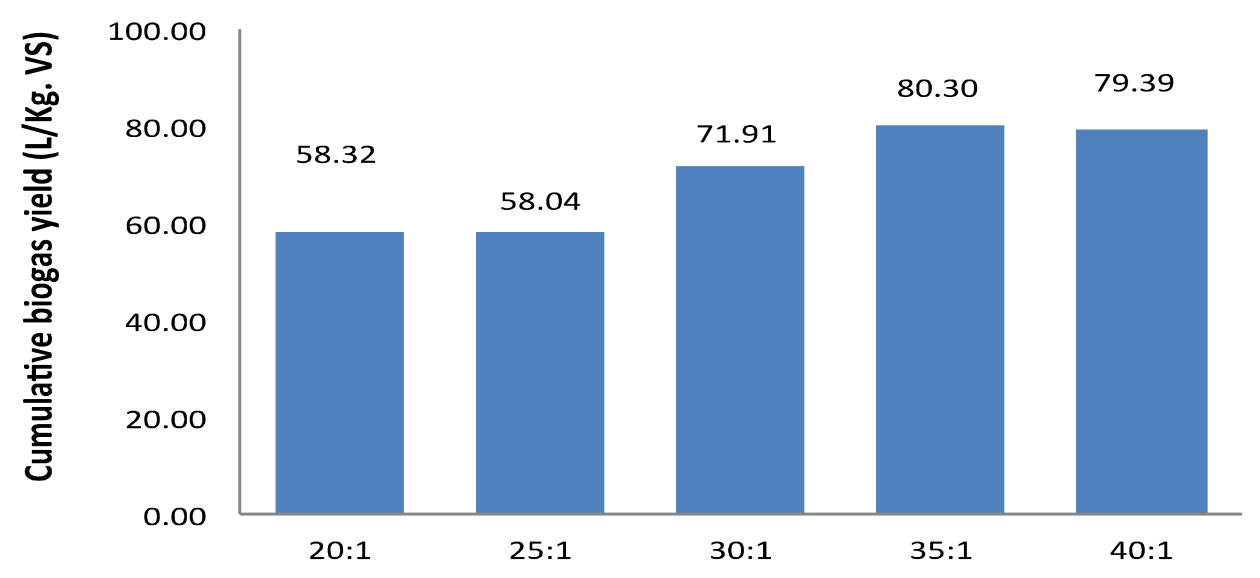

Mixing Ratio of POME and EFB

Fig.-7: Effect Ratio POME and EFB on Cumulative Biogas Production 
Table-2: Biogas Production for Various Mixing Ratio

\begin{tabular}{c|c}
\hline Mixing ratio & $\begin{array}{c}\text { Biogas Production } \\
\text { Cumulative (L/mg.VS) }\end{array}$ \\
\hline $20: 1$ & 58.32 \\
\hline $25: 1$ & 58.04 \\
\hline $30: 1$ & 71.91 \\
\hline $35: 1$ & 80.30 \\
\hline $40: 1$ & 79.39 \\
\hline
\end{tabular}

Figure-7 shows the column diagram of biogas produced from the fermentation process of POME and EFB. Cumulative biogas production increases from the ratio with the small amount of EFB to the ratio with the large EFB. The highest biogas production, $80.30 \mathrm{~L} / \mathrm{mg}$.VS was obtained at a mixing ratio of 35:1. According to a research conducted by Mattocks ${ }^{16}$, the organic loading rate (OLR) is a necessary parameter because it indicates the amount of VS to be incorporated in the fermentor which changes to biogas.

\section{Biogas Composition}

According to a research conducted by O-thong et al. ${ }^{20}$, high concentrations of empty fruit bunches substrates produced low methane, because high content of long chain fatty acids (LCFAs) in empty fruit bunch can decrease the decomposition process. Lipid-rich waste contains long-chain fatty acids; particularly high palmitate and higher oleates can inhibit bacterial growth and methane formation. The main components of biogas are methane $\left(\mathrm{CH}_{4}\right)$ and carbon dioxide $\left(\mathrm{CO}_{2}\right)$ and hydrogen sulphide $\left(\mathrm{H}_{2} \mathrm{~S}\right)$. The biogas composition for the various mixing ratio of palm oil mill effluent and empty fruit bunch is presented in Fig.-8.

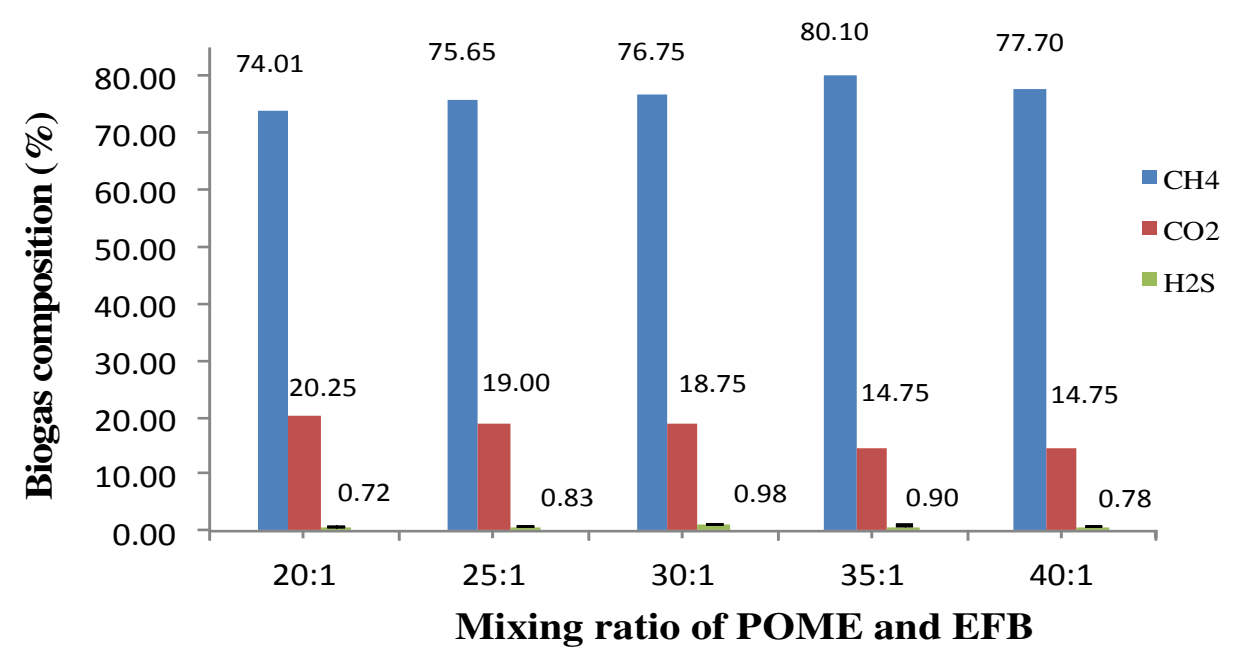

Fig.-8: The Biogas Composition for Various Mixing Ratio of POME and EFB

Figure- 8 shows the composition of biogas production. For various mixing ratio of POME and EFB the trend of the biogas composition is almost similar. In average the biogas production consisted of 76.84; $17.50 ; 0.84 \%$ of methane, carbon dioxide and hydrogen sulfide, respectively. The highest methane content, $80.10 \%$ was achieved by mixing ratio of POME and EFB 30:1.

\section{CONCLUSION}

This research has presented the possibility of anaerobic fermentation of EFB mixed with POME. During the process with a various mixing ratio of POME and EFB substrates were applied, the highest value of 
RASĀYAN J. Chem.

Vol. 11 | No. 2 |791 - 797 | April - June | 2018

biogas generation, $80.30 \mathrm{~L} / \mathrm{mg}$. VS was achieved at mixing ratio $35: 1$. At the same mixing ratio, highest methane content, $80.10 \%$ and highest COD reduction, $63.1 \%$ were achieved.

\section{ACKNOWLEDGMENT}

The authors gratefully acknowledge the support from Metawater Co. Ltd - Japan.

\section{REFERENCES}

1 Irvan, B. Trisakti, S. Maulina and H. Daimon, Rasayan J. Chem., 11(1), 378(2018), DOI: 10.13005/ojc/340118.

2 T. Wright and A. Rahmanulloh, USDA Foreign Agricultural Service, Global Agricultural Information Network GAIN, Report Number : ID1508 (2015).

3 G. Najafpour, H.A. Yieng, H. Younesi and A. Zinatizadeh, Process Biochem. 40(8), 2879(2005), DOI: $10.1016 /$ j.procbio.2005.01.002.

4 M.Y. Nurliyana, P.S. H'ng, H. Rasmina, M.S. Umi Kalsom, K.L. Chin W.C. Lum and G.D. Khoo, Ind. Crops Product. 76, 409(2015), DOI: 10.1016/j.indcrop.2015.04.047.

5 A. Embrandiri, P.F. Rupani, S. Quaik, M.H. Ibrahim and R.P. Singh, International Conference on Environmental, Biomedical and Biotechnology, IPCBEE, 4, (2012).

6 A. Allwar, Rasayan J. Chem., 11(1), 280(2018), DOI: 10.7324/RJC.2018.1112000.

7 Irvan, B. Trisakti, Y. Tomiuchi, U. Harahap and H. Daimon, IOP Conf. Series: Materials Sci. Eng., 206, 012094 (2017), DOI:10.1088/1757-899X/206/1/012094

8 Irvan, B. Trisakti, S. Maulina and H. Daimon, Oriental J. Chem., 34(1), 161(2018), DOI: $10.13005 / \mathrm{ojc} / 340118$.

9 APHA, Standard methods for the examination of water and wastewater, 20th ed. Washington (DC, USA): American Public Health Association, (1998).

10 M.H. Gerardi, The Microbiology of Anaerobic Digesters, Wiley-Interscience, New Jersey, 51-57 (2003).

11 K.F. Fannin and R. Biljetina, Reactor Design, In: I.P. Chynoweth, R. Isaacson, Anaerobic Digestion of Biomass. Elsevier Applied Science, London, New York, pp. 141(1987).

12 M. Faisal, A. Gani, F. Mulana and H. Daimon, Rasayan J. Chem., 9(2),133(2016).

13 R. Mehta, M.A. Barlaz, M. Asce and R.Y. Sinderson. J. Environ. Eng. 128(3), (2002), DOI: 10.1061/(ASCE)0733-9372(2002)128:3(228).

14 A. Babaee and J. Shayegan. World Renewable Energy Congress, Linkoping, Sweden. 8-13 May (2011).

15 F. Raposo, M.A. De la Rubia, V. Fernández-Cegrí and R. Borja. Renew. Sust. Energ. Rev., 16(1), 861(2012), DOI: 10.1016/j.rser.2011.09.008.

16 R. Mattocks, Understanding Biogas Generation, Technical Paper No. 4. Volunteers in Technical Assistance, Virginia, USA, p. 13 (1984).

17 S. Mujdalipah, S. Dohong, A. Suryani and A. Fitria. Agritech. 34(1), 56(2014).

18 W. Lerdrattranataywee and T. Kaosol Energy Procedia. 79, 327(2015), DOI:10.1016/j.egypro.2015.11.499.

19 J.D.R. Olvera and A.L. Lopez, Biogas Production from Anaerobic Treatment of Agro- Industrial Wastewater, Biogas, ISBN: 978-953-51-0204-5, InTech (2012).

20 S. O-Thong, K. Boe and I. Angelidaki, Appl. Energy, 93, 648(2012), DOI: 10.1016/j.apenergy.2011.12.092.

[RJC-3022/2018] 